\title{
A Market Study of Organic Food Products Available in Udaipur City, India
}

\author{
Nayana Sharma* and Ritu Singhvi \\ Department of Resource Management and Consumer Science, College of Home Science, \\ MPUAT, Udaipur, Rajasthan, India \\ *Corresponding author
}

\section{A B S T R A C T}

Keywords

Organic food market, Future growth, Food habit, Udaipur city

Article Info

Accepted:

06 July 2018

Available Online:

10 August 2018
The present study was conducted in the market of Udaipur city to know the present condition of organic food market. Data were collected with the help of structured and duly pre tested interview schedule. Result reveals that there were four main shops those were majorly selling organic food products range. The main aim for this study is to explore present market scenario and the major factors responsible for future growth of the organic food products business in Udaipur city. Since, there is a tremendous change in the last few years in our country of people consuming food habit. Now a day's people are more aware and health conscious therefore they prompt to go for safe and healthy food products. So, this factor will surely help in flourishing the business at large scale.

\section{Introduction}

Agriculture is one of the most important sector for shaping economy of our country India. There was a time in India that after independence there was food crises condition leading to food scarcity. As a result during 1960s, green revolution in India helped in becoming self-sufficient in food. Introduction of green revolution leads to improved irrigation, better varieties of crop, use of various chemical pesticides and fertilizers and better access to credit helped the agricultural sector take a break through. But in today's scenario due to green revolution the use of various chemical fertilizers and chemical pesticides in crops is now used in such an alarming rate that it is affecting our environment and health of living organisms. Excessive uses of chemicals in farming system have deteriorated soil, water and air quality. Now the use of these chemicals had reach to certain level that now production instead of increasing is either on downfall side or just reached to saturation.

So, its high time to combat the adversity caused by conventional method farming. This can be possible by doing sustainable agriculture i.e. organic farming. Organic farming forbidden the use of chemical and synthetic pesticides to produce food free from chemicals, of high nutritional quality and in sufficient quantity. Organic products market 
seems to be niche market for many of the farmers or manufactures. But this is what our ancestors were eating and leading healthy life. Now, there is the need to encourage farmers regarding practicing the organic farming at large scale by government. Government should certify the produce of farmers by organic certification with minimal fees so that the farmers can get good amount for their organic produce. Today's consumer, is however well aware about the fact that now there is the foremost need to switch over their food habits from non-organic food products to organic food products. But still majority of people are not aware about organic food or not easily access towards it. This is because of less production of organic food and there are few outlets selling organic food, which is another hindrance. Due to less production there was high market price of organic food, it is also the main factor which makes organic food not very popular among the people.

\section{Organic scenario world and Indian scenario}

Willer et al., (2008) reported that organic agriculture is now being practiced in more than 130 countries with a total area of 30.4 million hectares i.e., $0.65 \%$ of the total agricultural land of the world. With respect to the area under organic agriculture, Australia occupies the prime position followed by China, Argentina, USA, and Italy.

In a country like India, where labor is abundant and is relatively cheap, organic farming is seen as a good cost effective solution to the increasing costs involved in chemical farming as reported by Chandrashekar (2010). The increasing demand for organic food products in the developed countries and the extensive support of the Indian government coupled with its focus on agri-exports are the drivers for the Indian organic food industry.
The after effects of green revolution have encouraged the farmers to take up organic farming. In India, the cultivated land under certification is 2.8 million hectare only. The key issues emerging in organic farming include yield reduction in conversion to organic farm, soil fertility enhancement, integration of livestock, certification constraints, ecology, marketing and policy support. It has been argued that organic farming is productive and sustainable, but there is a need for strong support to it in the form of subsidies, agricultural extension services and research as analyzed by Reddy in 2010.

A study by Asadollahpour et al., in 2013 concluded that organic farming is being promoted in Iran to address environmental problems resulting from the use of chemical materials in agriculture. Despite many advantages of organic agriculture, the results of several case studies show that its adoption rate is still very low among farmers. In Iran, the cultivated land under certification is 7'256 hectare only. The results revealed that Iranian farmers have strong motives for the adoption, yet face challenges in certifying, marketing, and accessing reliable technical information and credits.

Pant et al., (2013) reported that India has increased 25 times area under organic farming in last 8 years from 2005 to 2012. Organic farming shows a growing trend, with total 10 , 20,000 hectares land used till 2012. Currently India's organic trade is above than Rs. 2,500 crores. For enhancing organic farming practices Ministry of commerce, started the National Programme on Organic Production. This national program involves the accreditation program for certification bodies, norms for organic production, promotion of organic farming. The National Programme on Organic Production standards for production and accreditation system has been recognized 
by the European Commission and Switzerland as equivalent to their country standards. Besides this, the Ministry of Agriculture also started various promotional schemes for small farmers. Fifteen Indian States have their own policy of organic farming since 2004, which is a good indication for Indian agriculture.

The Green revolution has been the greatest success story and has brought a spectacular increase in production and productivity in the country. But after initial success, the scenario has changed today with the quest of short term gains without due consideration of long term sustainability resources, particularly soil, water and environment have all now overstrained, and are getting increasingly depleted as reported by Kalidas et al., (2014). Now the concern is to sustain the agricultural and particularly crop production and productivity and take this agricultural sector to the frontier without damaging the resources and the environment. This will result in an alternative system of an optimal, balanced, efficient and scientific management of land, water, biodiversity and external inputs. Hence, the system of organic farming comes into the scenario.

Deshmukh and Babar (2015) revealed that India's total area under organic certification was 4.72 million hectare in 2013-14 and its global rank is $10^{\text {th }}$. The crop growth rate of cultivation of organic area of India was $11.52 \%$ of which wild collection was $12.57 \%$ and remaining area was $7.45 \%$ during 20052013. The co-efficient of variation was approximately $0.5 \%$ during same period. Compound growth rate of export quantity of organic products of India was $51.50 \%$ and export value was $11.75 \%$ during 2002-03 to 2013-14. Among all the States in India, Uttar Pradesh has highest area under organic farming followed by Himachal Pradesh, Madhya Pradesh and Maharashtra in 2011-12. India exports around 135 organic products of which the share of oil crops in total organic export quantity was $(26.74 \%)$ followed by cotton $(24.48 \%)$, basmati rice $(11.81 \%)$ in 2013-14. India is exporting organic products to all the continents of the world of which the largest share goes to EU (44.12\%) followed by USA (19.2\%).

Mitra and Devi (2015) reported that worldwide, over 37.5 million ha of land ( $0.87 \%$ of total agricultural land) is being managed organically by 1.9 million producers in 164 countries. In addition, there is another 31 million ha certified for wild harvest collection. Global sales of organic products have reached US $\$ 75$ billion, with the US and Europe as the largest consumers.

The concept of organic farming is not new to the Indian farming community. As of March 2014, India had 4.72 million ha land under an organic certification process, including 0.6 million ha of cultivated agricultural land and 4.12 million ha of wild harvest collection forest area. During 2012-2013, India exported 165,262 million tons of organic products across 135 commodities valued at US \$312 million. The domestic market for organic commodities is also growing at an annual growth rate of 15 to 20 per cent.

\section{Materials and Methods}

The study was conducted in Udaipur city of Rajasthan State. All the four shops were purposively selected as a sample to explored and collect the information regarding the various shops selling organic food products. During the market survey researcher found that there were four shops which where exclusively selling majority of organic food products. Hence, all the four shops were purposively selected as a sample to collect necessary information. The names of shops were as below: 


\section{Shop 1: Banyan roots organic store}

The board and the front view of organic shop can be seen in Plate 1 and Plate 2.

\section{Shop 2: Eco-fresh organics}

The front elevation of the organic food shop can be seen in Plate 3.

\section{Shop 3: Down to earth}

The board and front view of the organic food shop can be seen in Plate 4 and Plate 5.

\section{Shop 4: Grealth Agritech Pvt. Ltd}

An online store for organic food products. The logo of the store can be seen in Plate 6 .

The owners of all the four shops were selected as a sample for the market survey.

The researcher herself visited each shop selected as a sample for market survey and collected data with the help of developed interview schedule from the shopkeeper. The collected data was tabulated. The data collected from market survey was coded and decoded to formulate the comprehensive tables. The responses were analyzed using frequencies and percentages.

\section{Results and Discussion}

\section{Basic information}

Overall profile of the shop is presented underneath, which include name, address, type of the ownership and year of the establishment.

The data presented in Table 1 reveals that the establishment of fully fledged organic store for selling organic food products was started only eight years back in Udaipur city as the first organic food products shop was established in the year 2010 i.e. Grealth Agritech Private Limited. Later Banyan Roots in year 2011, Eco-Fresh Organics Shop in year 2013 and Bio Fresh Organics in year 2014 were established respectively. Out of these four shops three of them were having the ownership as sole proprietorship and one was having ownership as partnership company.

\section{Information on organic food products}

Results pertaining to the different type of products, certified food products, knowledge and importance of organic food certification, source of obtaining organic food products, characteristic of organic food and the perception about the increase in sale of organic food products in future as mentioned by selected shopkeepers are presented in this section.

Scrutiny of Table 2 unveils that there were only two shopkeepers who sold organic as well as non-organic food products and remaining two were selling organic food products with other organic products like organic clothing and organic beauty products.

Further, the data presented in Table reveals that out of four, only two shopkeepers sold solely certified organic food products as they directly purchased the certified products from the wholesalers/ retailers and further sell to the customers. Whereas, one of the shopkeeper sold few organic items with certification and few organic items without organic certification. The researcher wanted to know the reasons for selling certified and noncertified item, the shopkeeper expressed that he has taken the certification only for pulses and hence sells the certified pulses whereas for rest of the products he had not yet applied for organic certification. One shopkeeper sold organic food products without certification. 
Plate.1 Banyan roots organic store

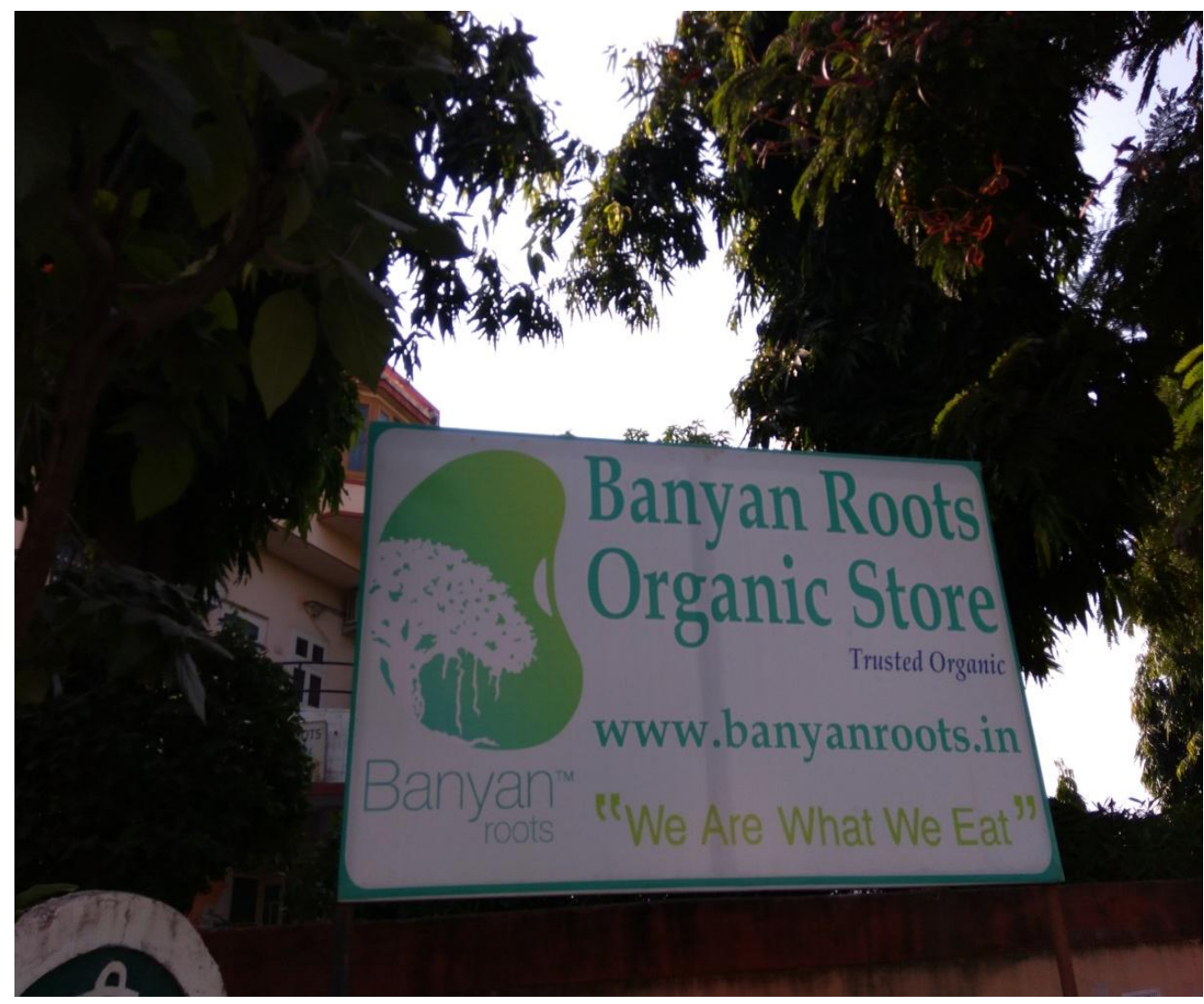

Plate.2 Front view of Banyan roots organic store

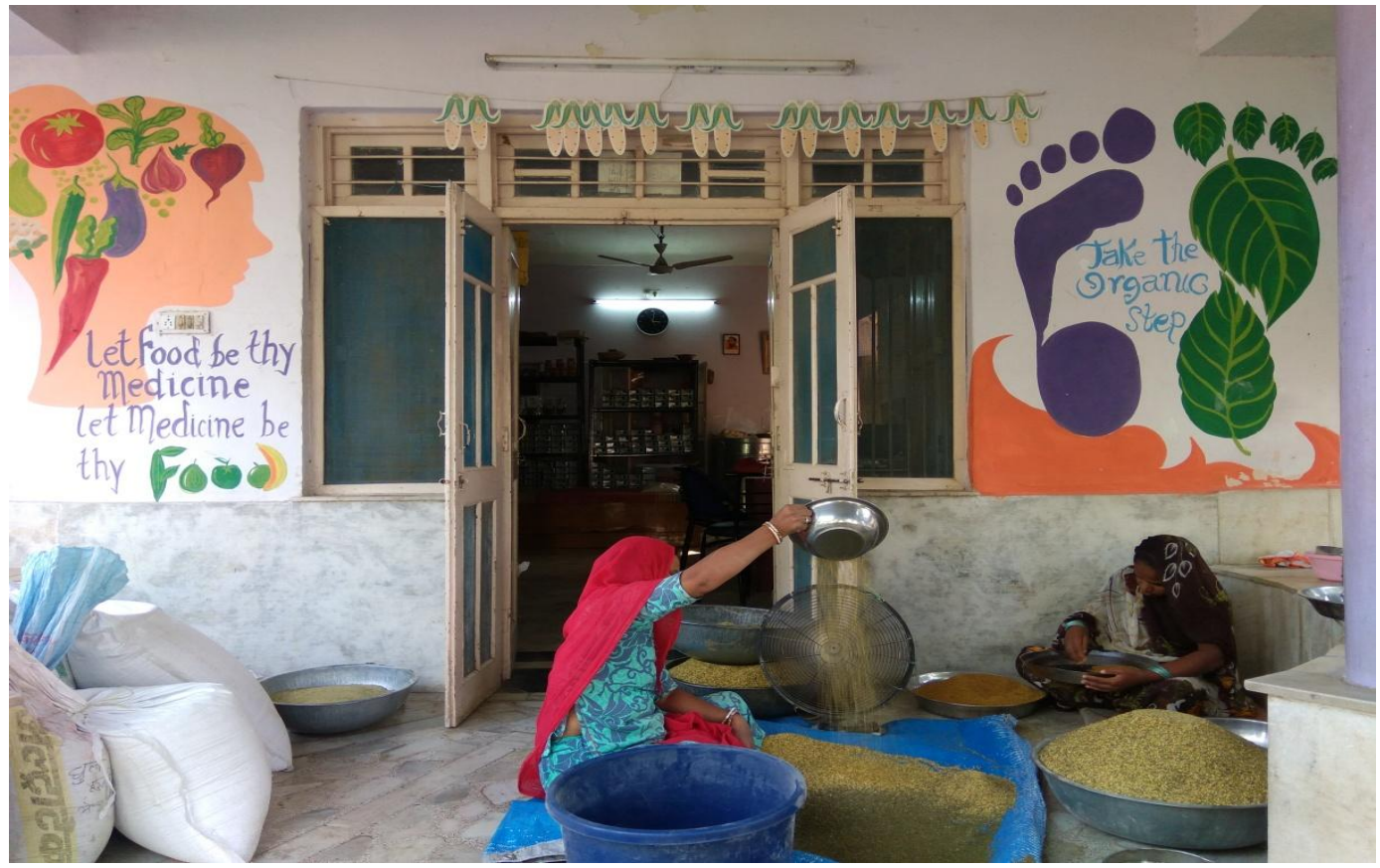


Int.J.Curr.Microbiol.App.Sci (2018) 7(8): 845-856

Plate.3 Front elevation of Eco-Fresh Organic

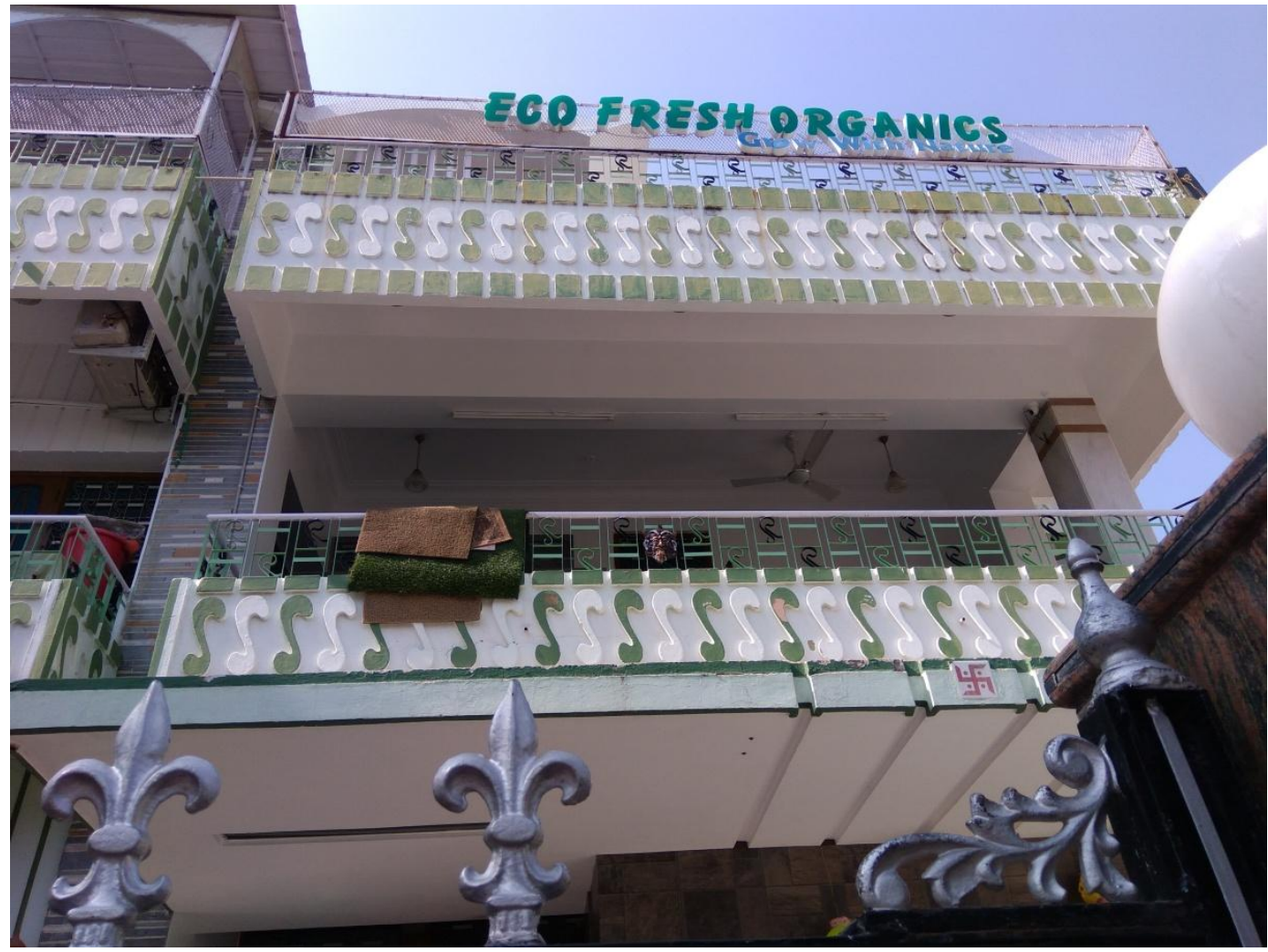

Plate.4 Board of down to earth certified organic shoppe

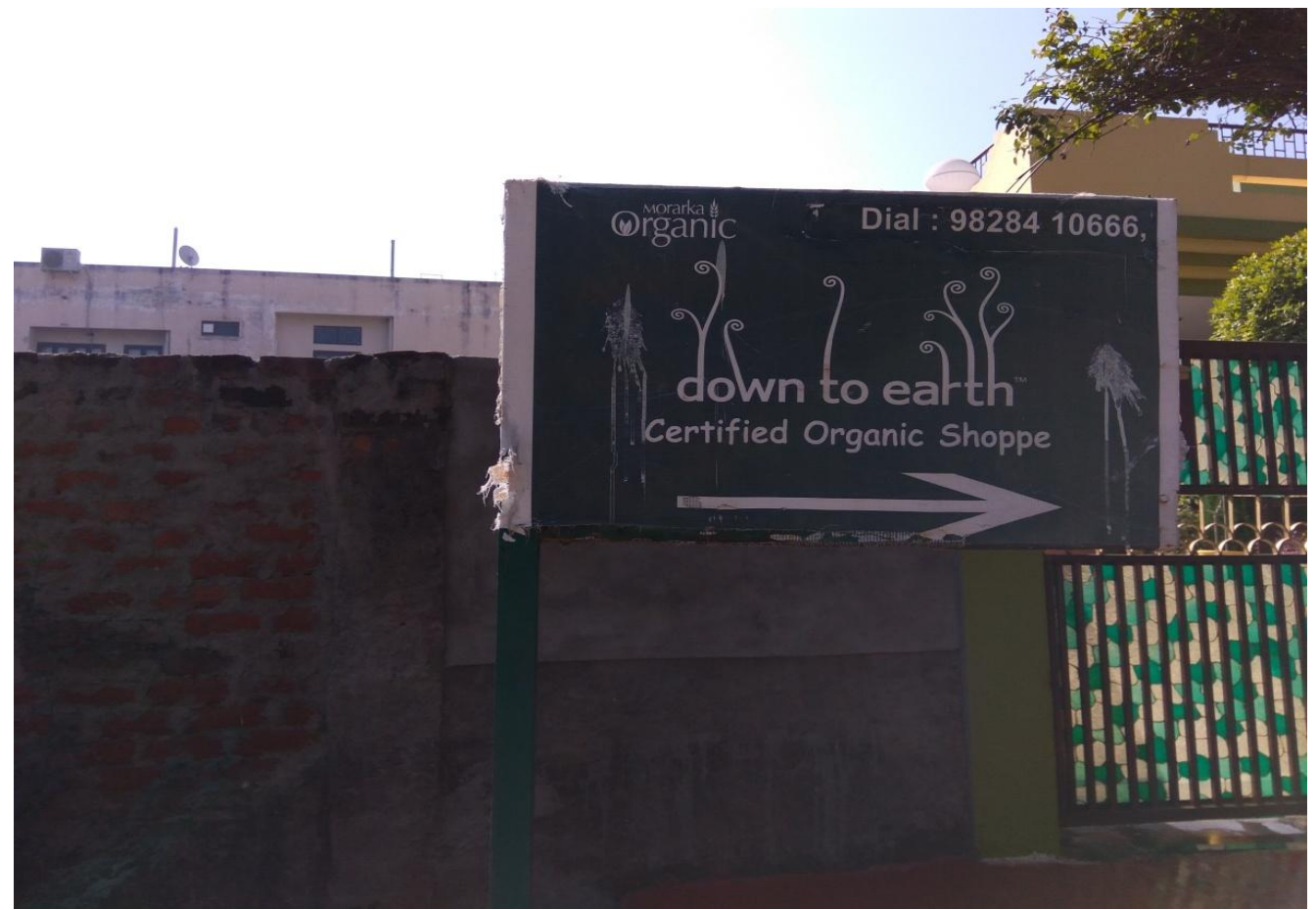


Plate.5 Front view of down to earth certified organic shoppe

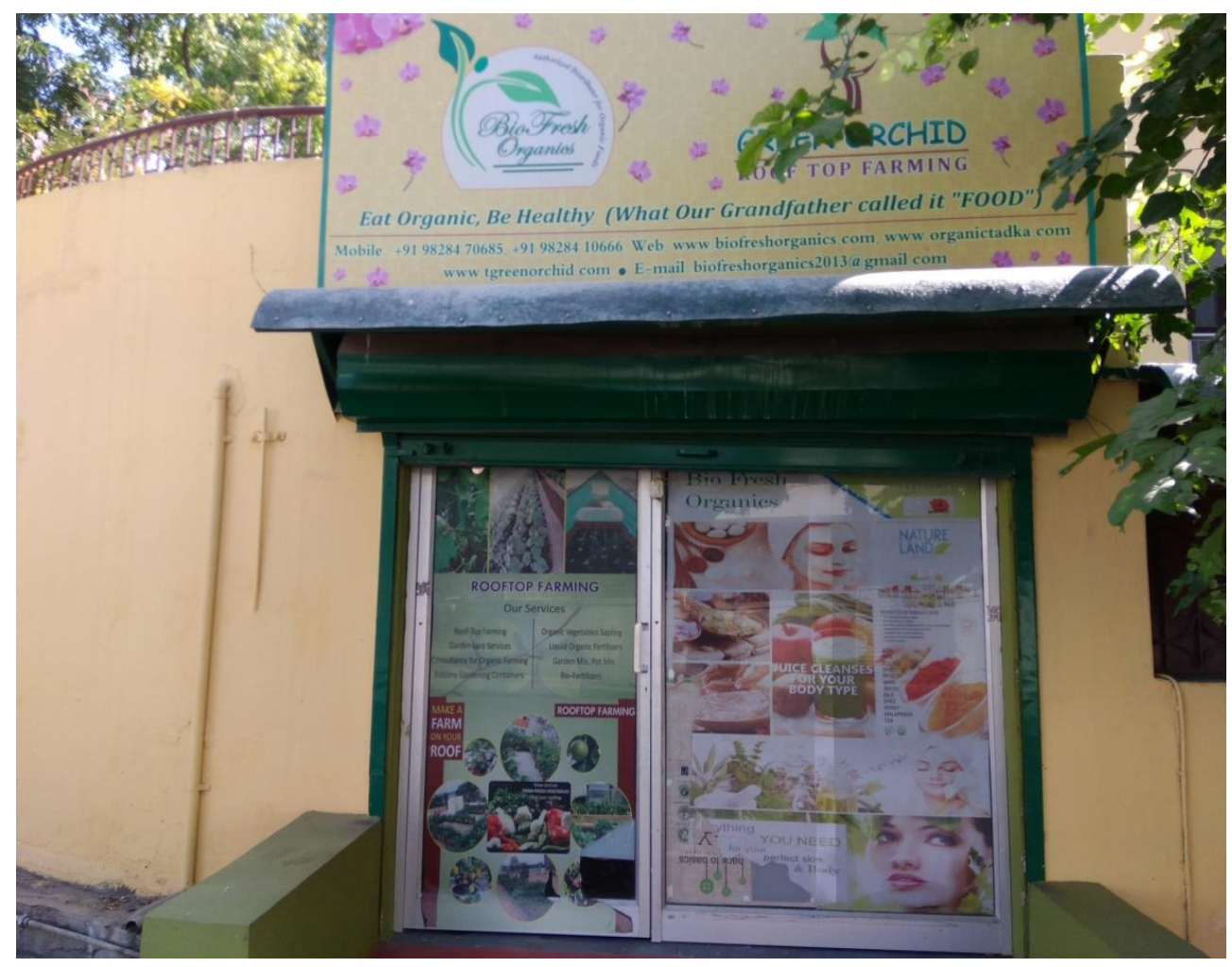

Plate.6 Logo of Grealth Agritech Pvt. Ltd

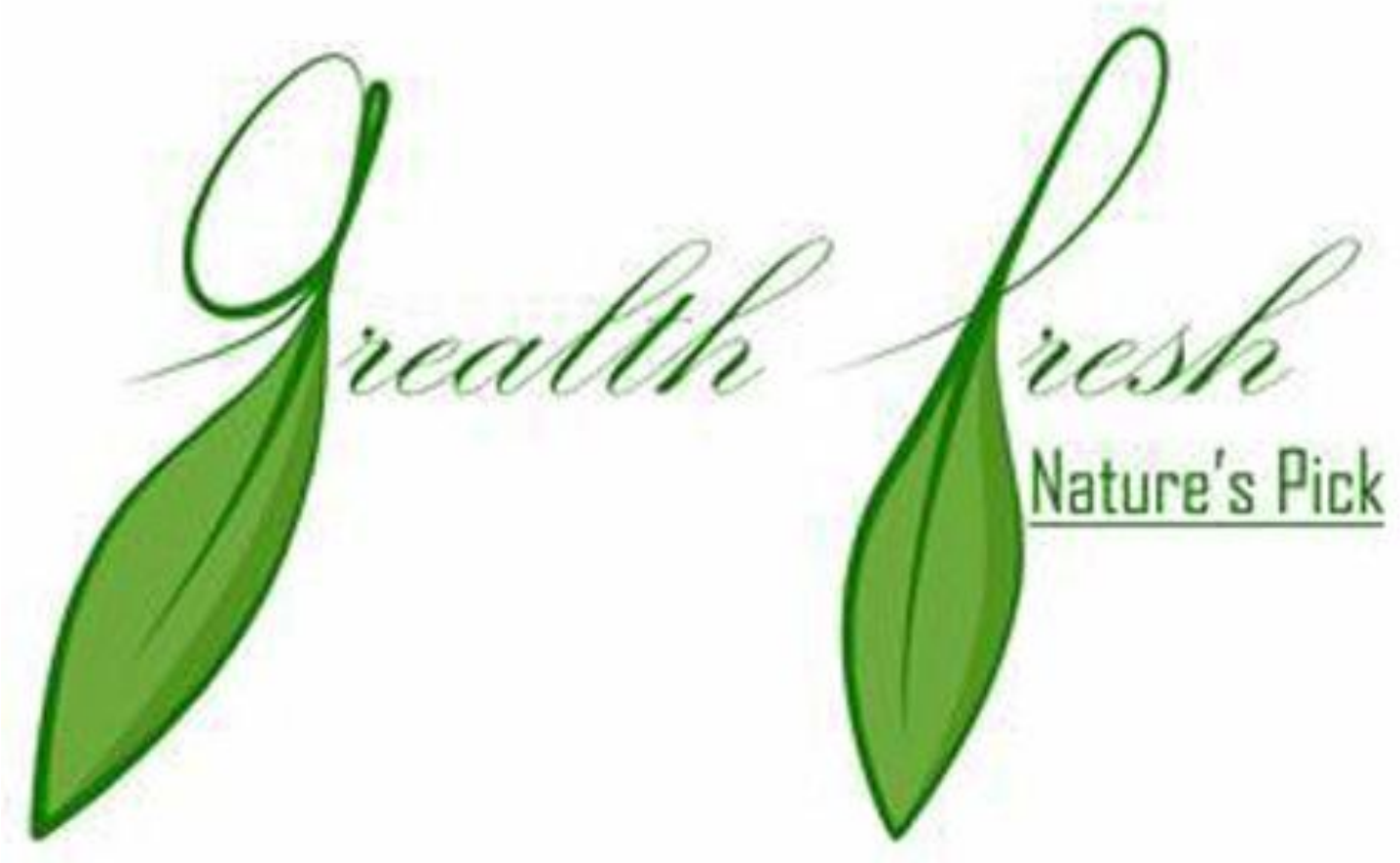


Plate.7 Organic food products displayed in two of the selected shops

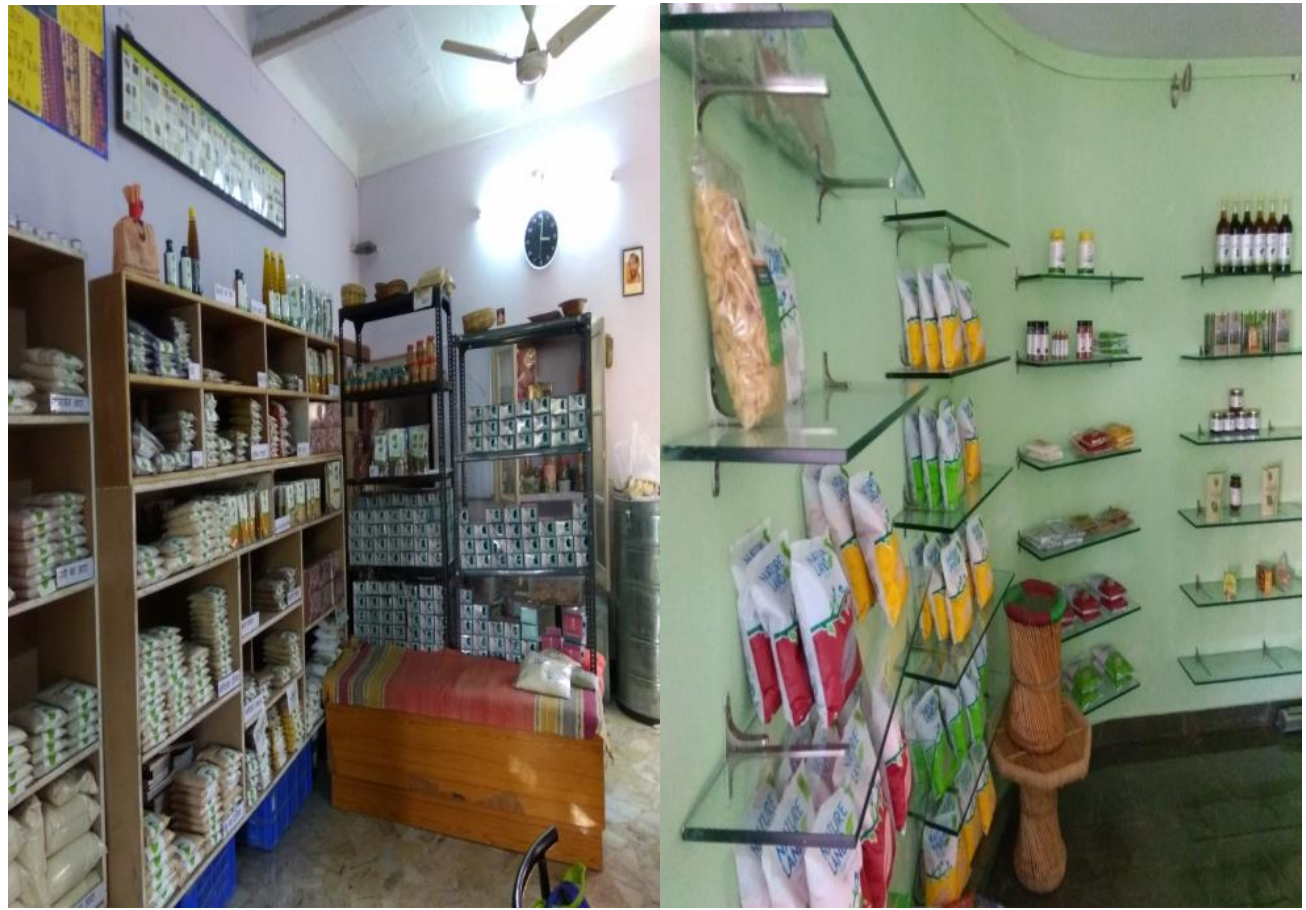

Table.1 Basic Information of selected enterprises selling organic food products

\begin{tabular}{|c|c|c|c|}
\hline $\begin{array}{l}\text { Sr. } \\
\text { No. }\end{array}$ & Name and address of the shop & $\begin{array}{l}\text { Type of } \\
\text { Ownership }\end{array}$ & $\begin{array}{l}\text { Year of } \\
\text { establishment }\end{array}$ \\
\hline 1. & $\begin{array}{l}\text { Grealth Agritech Private Limited } \\
\text { C/o Gayatri Seva Sansthan Campus, } \\
\text { Sector-6 Hiran Magri, Udaipur, } \\
\text { Rajasthan }\end{array}$ & $\begin{array}{l}\text { Partnership } \\
\text { company }\end{array}$ & 2010 \\
\hline 2. & $\begin{array}{l}\text { Banyan Roots } \\
\text { 33, Panchvati, Near R K Mall, } \\
\text { Opposite Gold Gym, Udaipur, } \\
\text { Rajasthan }\end{array}$ & $\begin{array}{l}\text { Sole } \\
\text { proprietorship }\end{array}$ & 2011 \\
\hline 3. & $\begin{array}{l}\text { Eco-Fresh Organics Shop } \\
\text { 1-Shivaji Nagar, Opposite R.S.S } \\
\text { Office, Inside Udaipole, Udaipur, } \\
\text { Rajasthan }\end{array}$ & $\begin{array}{l}\text { Sole } \\
\text { proprietorship }\end{array}$ & 2013 \\
\hline 4. & $\begin{array}{l}\text { Bio Fresh Organics } \\
58-B \text { Bio Fresh Organics, } \\
\text { Ambamata Scheme, Udaipur, } \\
\text { Rajasthan }\end{array}$ & $\begin{array}{l}\text { Sole } \\
\text { proprietorship }\end{array}$ & 2014 \\
\hline
\end{tabular}


Table.2 Type and certified food products sold

\begin{tabular}{|c|c|c|c|c|c|}
\hline $\begin{array}{l}\text { Sr. } \\
\text { No. }\end{array}$ & Products & $\begin{array}{l}\text { Shopkeeper } \\
1\end{array}$ & $\begin{array}{l}\text { Shopkeeper } \\
2\end{array}$ & $\begin{array}{l}\text { Shopkeeper } \\
3\end{array}$ & $\begin{array}{l}\text { Shopkeeper } \\
4\end{array}$ \\
\hline A. & \multicolumn{5}{|l|}{ Type } \\
\hline 1. & Only organic food products & - & - & - & - \\
\hline 2. & $\begin{array}{l}\text { Organic as well as non } \\
\text { organic food products }\end{array}$ & $\checkmark$ & - & - & $\checkmark$ \\
\hline 3. & $\begin{array}{l}\text { Organic food products with } \\
\text { other organic products like } \\
\text { organic clothing and organic } \\
\text { beauty products }\end{array}$ & - & $\sqrt{ }$ & $\sqrt{ }$ & - \\
\hline B. & \multicolumn{5}{|l|}{ Certified products } \\
\hline 1. & $\begin{array}{l}\text { Solely certified organic food } \\
\text { products }\end{array}$ & - & $\checkmark$ & $\checkmark$ & - \\
\hline 2. & $\begin{array}{l}\text { Few organic items with } \\
\text { certification and few organic } \\
\text { items without organic } \\
\text { certification }\end{array}$ & - & - & - & $\checkmark$ \\
\hline 3. & $\begin{array}{l}\text { Organic food products } \\
\text { without certification }\end{array}$ & $\checkmark$ & - & - & - \\
\hline
\end{tabular}

Table.3 Distribution of shopkeepers according to the knowledge about organic food certification

\begin{tabular}{|c|c|c|}
\hline $\begin{array}{l}\text { Sr. } \\
\text { No. }\end{array}$ & Particulars & Percentage \\
\hline A. & Knowledge about organic food certification & \\
\hline 1. & Institution providing the certification & 100 \\
\hline 2. & Process of applying organic certification & 100 \\
\hline 3. & Fee structure & 100 \\
\hline 4. & Auditing document & 100 \\
\hline 5. & Regular field inspection & 100 \\
\hline 6. & Compliance verification & 100 \\
\hline 7. & Duration of getting the certification & 100 \\
\hline 8. & Validation period of organic certification & 100 \\
\hline B. & Importance of organic food certification & \\
\hline 1. & Serves as a marketing tool & 75 \\
\hline 2. & No need of convincing buyers & 75 \\
\hline 3. & Serves as a sales promotional tool & 75 \\
\hline 4. & Builds positive image & 75 \\
\hline 5. & Develop trust among customers & 75 \\
\hline 6. & No bargaining & 75 \\
\hline
\end{tabular}


Table.4 Sources for procuring organic food products by shopkeepers

\begin{tabular}{|l|l|c|}
\hline $\begin{array}{c}\text { Sr. } \\
\text { No. }\end{array}$ & \multicolumn{1}{|c|}{ Sources } & Percentage \\
\hline 1. & Only from own farm & - \\
\hline 2. & Both from own and others farm & 50 \\
\hline 3. & From wholesalers/ retailers & 50 \\
\hline
\end{tabular}

Table.5 Characteristics of organic food as mentioned by shopkeepers

\begin{tabular}{|l|l|c|}
\hline $\begin{array}{l}\text { Sr. } \\
\text { No. }\end{array}$ & Organic food & Percentage \\
\hline 1. & Chemical pesticide free & 100 \\
\hline 2. & Chemical fertilizer free & 100 \\
\hline 3. & Eco-friendly & 100 \\
\hline 4. & Fresh & 75 \\
\hline 5. & Healthier & 75 \\
\hline 6. & More nutritious & 75 \\
\hline 7. & Free from genetically modified organisms & 50 \\
\hline
\end{tabular}

Table.6 Frequency distribution of the respondents as per the perception about the increase in sale of organic food products in future

\begin{tabular}{|l|l|l|l|l|l|}
\hline Sr. No. & Perception & Shopkeeper 1 & Shopkeeper 2 & Shopkeeper & Shopkeeper 4 \\
\hline & & $\checkmark$ & - & - & - \\
\hline 2. & Agree & - & $\checkmark$ & - & $\checkmark$ \\
\hline 3. & Neutral & - & - & $\checkmark$ & - \\
\hline 4. & Disagree & - & - & - & - \\
\hline 5. & Strongly disagree & - & - & - & - \\
\hline
\end{tabular}

It was expressed by the shopkeeper that he sold only uncertified organic food products as the process of getting certification is time consuming and too expensive which will further increase the cost of organic food products and in Udaipur city it is difficult to find the good number of customers to buy the organic food stuffs.

Shopkeeper further expressed that he may take the certification of the organic food products in the years to come.
Reasons behind this were increased awareness, growing importance of organic food and willingness to pay more for these products among consumers.

All the shopkeepers had knowledge about the complete information as mentioned in Table 3 about organic food certification. It includes the information regarding institution providing the certification, process of applying for organic certification, fee structure, auditing document, regular field inspection, compliance verification, duration 
of getting the certification and validation period of organic certification. As far as importance is concerned they know the importance of organic food certification as it helps the shopkeeper to sale the product without much of convincing and promotional activities. It also builds the positive image and develops trust among customers. Whereas one shopkeeper had the opinion that certification of organic food products is not of much importance as once the organic food product is purchased by the consumers will automatically realize its quality and importance and will buy repeatedly. Certification is not of great importance in case of organic food products which may unnecessarily put cost pressure on the consumer.

Scrutiny of Table 4 indicates that half of the shopkeepers i.e. 50 per cent procured the organic food products produced on their own farm as well as from others farm. The reason for procuring from both sources was that certain food produce were grown on their own farm whereas few products which were grown on other farms in the city, as well as other States were also procured.

During collecting the information the investigator also observed that the organic food were purchased in the large quantity and packed them into different quantities using their own packaging as well as label information. Remaining 50 per cent shopkeepers neither had their own farm nor purchased from others farm as they were procuring total range of organic food products in the form of packaged food items from wholesalers/retailers.

It is evident from Table 5 that cent per cent of the shopkeepers mentioned that the organic food products are chemical pesticide free, chemical fertilizer free and eco-friendly. Out of four shopkeepers three shopkeepers said that organic food remains fresh for longer duration and considered to be healthier and more nutritious than non-organic food. Whereas fifty percent of the shopkeepers considered that organic food is free from genetically modified organisms. This allow the investigator to extrapolate that majority of the shopkeepers were aware about that organic food products are better as compared to non-organic food products in many characteristics.

Table 6 describes the perception about the increase in sale of organic food products in future. The shopkeepers' perception was dependent upon the current sale of organic food products. Only one shopkeeper strongly agreed with the fact that looking at the present scenario of customers purchasing behavior the sale of organic food products will surely be increased in future. Whereas on other hand two owners have just agreed with the fact that in near future demand of organic food will increase but there is the need of increased awareness among the consumers regarding organic food products. One out of four owners was neutral in expressing his perception about increase in sale of organic food products in the future. He said he was not sure about increase or decrease in future sale. None of them disagreed and strongly disagreed that the future sale of organic food products will not increase.

In all there were only four shops selling majority of organic food products in the market of Udaipur city started only eight years back in Udaipur city. There were only two shopkeepers who sold organic as well as non-organic food products and remaining two were selling organic food products with other organic products. Only two shopkeepers sold solely certified organic food products as they directly purchased it from the wholesalers/ retailers. Whereas, one of the shopkeeper sold few organic items with certification and few 
organic items without organic certification. One shopkeeper sold all the organic food products without certification. All the four shopkeepers had knowledge about organic food certification.

As far as importance is concerned they knew the importance of organic food certification as it helps the shopkeepers to sell the products without much of convincing and promotional activities. Whereas one shopkeeper had the opinion that certification of organic food products is not of much importance.

Two shopkeepers procured the organic food products produce on their own farm as well as from others farm. Remaining two shopkeepers neither had their own farm nor purchased from others farm as they were procuring total range of organic food products in the form of packaged food items from wholesalers/retailers. Cent per cent of the shopkeepers mentioned that the organic food products are chemical pesticide free, chemical fertilizer free and eco-friendly.

The above study shows that still there is the need of more number of certified organic shops in market. The market of organic food is just handful and need to be promoted by the government among farmer (producer) and consumer so that a profitable business can be run successfully.

\section{References}

Asadollahpour, A., Pirmoradi, A. and Mohammadi, S.S. 2013. Organic farming: status, challenges and barriers - an Iranian perspective. J. Agri-Food Appl. Sci. 1: 110-118.

Chandrashekar, H.M. 2010. Changing scenario of organic farming in India: an overview. Int. NGO J., 5: 34-39.

Deshmukh, M.S. and Babar, N. 2015. Present status and prospects of organic farming in India. Eur. Acad. Res. 3: 4271-4287.

Kalidas, K., Darthiya, M., Malathi, P. and Thomas, L. 2014. Organic coconut cultivation in India - problems \& prospects. Int. J. Sci. Res. 3: 14-15.

Mitra, S. and Devi, H. 2015. Organic horticulture in India. Horticulturae. 2: $1-6$.

Pant, A.K., Kumar, K. and Mishra G.C. 2013. Statistical review: worldwide use of organic farming practices. Popular Kheti. 1: 1-4.

Reddy, B.S. 2010. Organic farming: status, issues and prospects - a review. Agri. Econ. Res. Rev. 23: 343-358.

Willer, H., Yussefi, M. and Sorensen, N. 2008. The world of organic agriculturestatistics and emerging trends 2008. http://orgprints.org/13123/4/world-oforganic-agriculture-2008.pdf.

\section{How to cite this article:}

Nayana Sharma and Ritu Singhvi. 2018. A Market Study of Organic Food Products Available in Udaipur City. Int.J.Curr.Microbiol.App.Sci. 7(08): 845-856.

doi: https://doi.org/10.20546/ijcmas.2018.708.095 